\author{
KATARZYNA MIDOR \\ WITOLD BIAEY \\ JURAJ RUŽBARSKÝ
}

\title{
Significance of chain quality in work safety
}

\begin{abstract}
From the point of view of the working environment, the quality of the chain used in lifting devices is very important. An important element in hoists and cranes is the short link chain, which largely affects the safety of the worker operating the crane. The article discusses the basic elements affecting the quality and safety of a chain. This analysis clearly shows that, when choosing a supplier, users of these products should be guided not only by the price but, above all, the certificates and attestations that the manufacturer provides for the product.
\end{abstract}

Key words: chain, hoist/winch, quality, work safety

\section{INTRODUCTION}

The work environment exerts a great influence on the health and quality of life of the employee, as it is made up of a set of material and psycho-social factors that the employee comes into contact with during their work or preparation for it. The material factors of the work environment include (among others) the premises of an enterprise or institution, buildings, rooms, machines, tools, and devices along with factors of a physical and chemical nature (e.g., microclimate, lighting, vibrations, noise, mechanical factors, and chemical or dust substances) as well as biological agents. In contrast, psychosocial (non-material) factors in the work environment include psychological demands, organizational factors, employee participation, interpersonal relationships, career development, and organizational culture, among others $[1,2]$.

The article discusses one of the elements of the work environment in the industry affecting worker safety; namely, the hoisting equipment, an important operational element of which is a chain.

Cranes are a group of lifting and transporting devices used to move loads, animals, and people vertically or horizontally for short distances in intermittent motions. In the classic literature [3], we can distinguish jacks, lifts, trolleys, gantries, and cranes in the division of hoisting equipment. Due to the issues raised in the present article, the authors are interested in cranes, which are divided into such devices as winches and hoists, among others. These two devices (cranes) are designed for the vertical lifting of a load by means of a rope or chain with the use of a gripping element, usually a hook; the difference between them consists of the attachment of the supporting structure. Depending on the design, these devices can be used in various areas such as heavy construction and the automotive or wood industries [4].

In many cranes (especially hand-operated ones), chains are used as the lifting element. The chains are also used as components of hoisting chains for tying and hanging loads on the hooks of manual and mechanical lifts.

Chains used in cranes as lifting elements can be divided into two types: link chains and plate link chains (also known as Gall's chains) - Figure 1. These two types of chains are called technical chains, which are irreplaceable in many branches of industry and economy and are designed to carry larger loads. a)

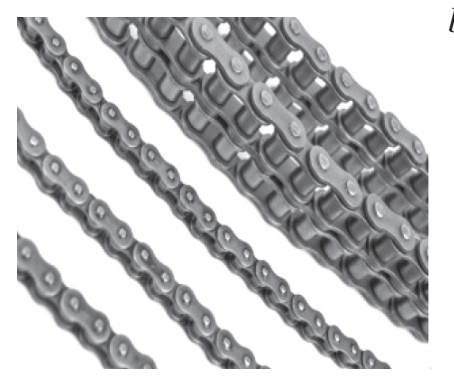

b)



Fig. 1. Gall's roller drive chain (a); link lifting chain (b)

The basic characteristic of a chain is the so-called chain size. This value is defined as the product of the 
diameter of the bar from which the link is made (d) and the largest internal dimension " $p$ " called the chain pitch. In addition, the link is characterized by the following values: "a" - the internal length measured in the link's light; "b" - the outer link width; and "L11p" - the internal length of a chain with 11 links [5]. The dimensions of a link are presented in Figure 2. Depending on the length of the link, we divide chains into short- and long-linked ones. A shortlink chain is a chain whose link length does not exceed 5 times the diameter of the rod from which the link is made (d) and the width (b) is not greater than 3.5 times the diameter of the bar. If the link length exceeds 5 times the diameter of the bar (d), a chain is classified as a long-link one.

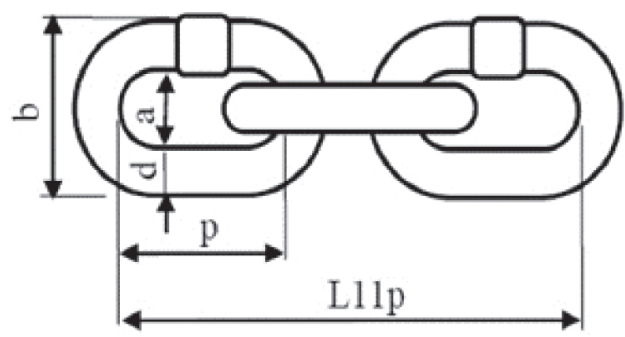

Fig. 2. Dimensions of link/chain [5]

Short-link chains are used in a number of mechanical devices, mainly as drive chains cooperating with socket wheels and support slings in hoists. Chains with long links are general-purpose chains and are used especially in the mining industry.

In the article, attention will be given to chains with short links, which are used primarily in hoists and winches.

Depending on the type of drive, hoists can be divided into manual, electric, and pneumatic devices. On the other hand, the division due to the type of band used divides these devices into chain or rope ones. Examples of such hoists are presented in Figure 3. a)

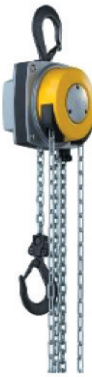

b)

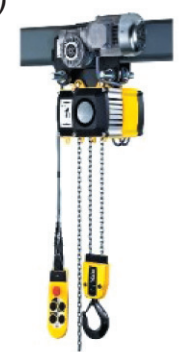

c)

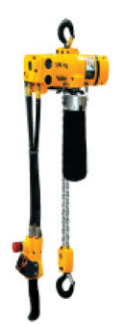

Fig. 3. Examples of hoist types: a) yale lift 360 manual chain hoist; b) CPV electric drive chain hoist;

c) CPA 1-13 pneumatic drive chain hoist
Chains with short links for lifting loads can be used in many industrial and economic sectors, including in the underground excavations of mines as well as in areas with coal dust and methane explosion hazards, among others.

There are several manufacturers of such chains on the Polish market: Pewag Poland Sp. z o.o., Grupa RUD, THIELE, and Retezarna a.s., among others.

\section{LEGAL REQUIREMENTS FOR CHAINS WITH SHORT LINKS}

In the mining industry, chain hoists are used for short-distance transport, which enables the assembly of machine and equipment components as well as the transfer of materials. Due to the difficult operating conditions in limited spaces of excavations and assembly chambers, hoisting equipment intended for the mining industry must be characterized by high lifting speed, low weight, small dimensions, and operational safety in addition to the appropriate lifting capacity [6].

An important operating element in these devices is the chain, which largely determines the safety of the worker operating the crane. Each chain used in industry within the European Union must comply with Directive 2006/42/EC of the European Parliament and of the Council of May 17, 2006, on machinery, which refers to the safety and protection of the health of workers working with devices and machines whose moving element is a chain, among other things. Therefore, chains intended for lifting loads that are normally used in the EU (including Poland) must be manufactured in accordance with the above directive and with the requirements of such standards as:

- EN 818-2 + A1. The standard for medium tolerance chains for chain clamps - Class $8(800 \mathrm{MPa})$ characterized by the ratio of safety factors $4: 2.5: 1$ (breaking force/test force/load capacity). The chain must be tested. The temperature limits are $-40^{\circ}$ to $+400^{\circ} \mathrm{C}$

- EN 818-7 + A1. The standard describing the requirements for the chain of a hoist/chain winch depending on the design, weight of the load, and environment in which it is used.

A $T$ chain used in hoists/winches with manual drives or in hoists with low speed motor drives that do 
not work under abrasive conditions. The chain safety factor should have a ratio of $4: 2.5: \mathrm{x}$ (breaking force/ test force/load capacity in accordance with ISO 4301-1 drives). The chain should be calibrated and tested. The temperature limits are $-40^{\circ} \mathrm{C}$ to $+200^{\circ} \mathrm{C}$.

A DAT chain is used in hoists/winches with motor drives that reach high speeds combined with high work intensity in places where resistance to abrasion is required; this is connected with increasing the durability of the chain. The safety factor should have a ratio of $4: 2.5: \mathrm{x}$ (breaking force/test force/load capacity in accordance with ISO 4301-1 drives). The chain should be calibrated and tested. The temperature limits are $-20^{\circ} \mathrm{C}$ to $+200^{\circ} \mathrm{C}$.

A DT chain used in hoists/winches with motor drives operating in abrasive working conditions. The safety factor should have a ratio of $4: 2.5: \mathrm{x}$ (breaking force/test force/load capacity in accordance with ISO 4301-1 drives). The chain should be calibrated and tested. The temperature range is $-10^{\circ} \mathrm{C}$ to $+200^{\circ} \mathrm{C}$.

In addition, the following technical standards and legal acts are in force in Poland, whose fulfilment guarantees the chain user's safety. These are (among others) such documents as:

- PN-G-46732:1997: Mining chain hoists - calibrated short-link chains;
- Safety requirements considering the provisions of the "Geological and Mining Law" Act of June 9, 2011 (Journal of Laws of 2017, item 2126, as amended);

- Regulation of the Minister of Economy of June 28, 2002, on work health and safety, operation, and specialized fire protection in underground mining facilities (Journal of Laws of 2002, No. 139, Item 1169);

- Act of December 12, 2003, on general product safety (Journal of Laws of December 31, 2003);

- PN-EN 10025:2002: Hot-rolled products made of structural steel;

- PN-EN ISO 643:2013-06: Steel - Micrographic grain size determination;

- PN-EN ISO 6507-1:2018-05: Metals - Vickers hardness measurement - Part 1: Test method.

\section{TECHNICAL REQUIREMENTS FOR CHAINS WITH SHORT LINKS}

The Retezarna a.s. company has chains of standard sizes in its offer, which are presented in Table 1. In addition to the standard sizes, custom chains can be produced at the customer's special request [5].

Link chains are made of steel with tensile strengths suitable for any given chain class. They consist of links welded in fire or electrically.

Table 1

Standard chain sizes offered by Retezarna a.s. [5]

\begin{tabular}{|c|c|c|c|c|c|c|c|c|c|}
\hline $\begin{array}{l}\text { Chain size } \\
\quad d \times p\end{array}$ & & & $p$ & $\begin{array}{c}a \text { no } \\
\text { lower } \\
\text { than }\end{array}$ & $\begin{array}{c}b \text { no } \\
\text { greater } \\
\text { than }\end{array}$ & \multirow{2}{*}{$\begin{array}{c}\begin{array}{c}\text { Weight } \\
\text { of } 1 \mathrm{~m} \\
\text { of chain }\end{array} \\
{[\mathrm{kg}]}\end{array}$} & $\begin{array}{c}\text { Nominal } \\
\text { length } \\
L=11 \times p\end{array}$ & Tolerance & \multirow[t]{2}{*}{$\begin{array}{l}\text { Max. weld } \\
\text { diameter }\end{array}$} \\
\hline \multicolumn{6}{|c|}{$[\mathrm{mm}]$} & & \multicolumn{2}{|c|}{$[\mathrm{mm}]$} & \\
\hline $4 \times 12$ & 4 & \pm 0.2 & 12 & 4.8 & 13.6 & 0.35 & 132 & 0.6 & 4.3 \\
\hline $5 \times 15$ & 5 & \pm 0.2 & 15 & 6.0 & 17.0 & 0.54 & 165 & 0.8 & 5.4 \\
\hline $6 \times 18$ & 6 & \pm 0.2 & 18 & 7.2 & 20.4 & 0.8 & 198 & 1.0 & 6.5 \\
\hline $7 \times 21$ & 7 & \pm 0.3 & 21 & 8.4 & 23.8 & 1.1 & 231 & 1.1 & 7.6 \\
\hline $8 \times 24$ & 8 & \pm 0.4 & 24 & 9.6 & 27.2 & 1.4 & 264 & 1.3 & 8.6 \\
\hline $9 \times 27$ & 9 & \pm 0.4 & 27 & 10.8 & 30.6 & 1.8 & 297 & 1.4 & 9.7 \\
\hline $10 \times 30$ & 10 & \pm 0.4 & 30 & 12.0 & 34.0 & 2.2 & 330 & 1.6 & 10.8 \\
\hline $11 \times 31$ & 11 & \pm 0.4 & 31 & 13.2 & 37.4 & 2.7 & 363 & 1.7 & 11.9 \\
\hline $12 \times 36$ & 12 & \pm 0.5 & 36 & 14.4 & 47.6 & 3.1 & 396 & 1.9 & 13.0 \\
\hline $13 \times 39$ & 13 & \pm 0.5 & 39 & 15.6 & 44.2 & 3.7 & 429 & 2.1 & 14.0 \\
\hline $14 \times 42$ & 14 & \pm 0.6 & 42 & 16.8 & 47.6 & 4.3 & 462 & 2.2 & 15.1 \\
\hline $16 \times 45$ & 16 & \pm 0.6 & 45 & 19.2 & 54.4 & 5.6 & 528 & 2.5 & 17.3 \\
\hline $18 \times 54$ & 18 & \pm 0.9 & 54 & 21.6 & 61.2 & 7.0 & 594 & 2.9 & 19.4 \\
\hline $20 \times 60$ & 20 & \pm 1.0 & 60 & 24.0 & 68.0 & 8.7 & 660 & 3.2 & 21.6 \\
\hline $22 \times 66$ & 22 & \pm 1.1 & 66 & 26.4 & 74.8 & 10.5 & 726 & 3.5 & 23.8 \\
\hline
\end{tabular}


Welded chains for T-class chain hoists and winches (T, DAT, DT) must be characterized by high quality, excellent usability, and long service life. To achieve this, they must be manufactured with the utmost care so as to ensure safety during their use.

The parameters determining the quality and safety of chains are their mechanical properties and loads, among others. For the production of chains for winches/hoists, steel with mechanical properties in accordance with PN-EN 10025 [7-9] is used so that the final product meets all of the requirements set out by the stringent European norms in accordance with the PN-EN 818-7 and PN-G-46732 standards. The EN8-18-7 + A1: 2008 European standard (which is also in force in Poland) sets out clearly defined requirements for the type of steel the chain is made of, the process in which the steel is made, and what its chemical composition should be. Tables 2 and 3 present the requirements for the content of specific elements in the steel.

In order to protect the chain against aging during its use, the steel should contain at least $0.025 \%$ aluminum (Al).

Another important element affecting the safe use of a chain is its quality, with particular attention to deviations from the dimensions that were included in Table 1. In addition, PN-EN 818-7 requires the manufacturer to use a complex program of product quality tests to ensure a chain's safety during its operation.
Particular emphasis is placed on the use of the appropriate steel grades as materials from which T-class short chain elements are made. Each delivery to the customer must be marked with the manufacturer's mark, chain thickness, production batch number, chain length, and number of pieces in the series. At the end of every meter of a chain, there is a mark containing the manufacturer's mark, year of production, number denoting the month of production, and chain's class (T, DAT, or DT - for the 818-7 standard; 5.6 or 8 for the PN-G-46732 standard) - Figure 4.

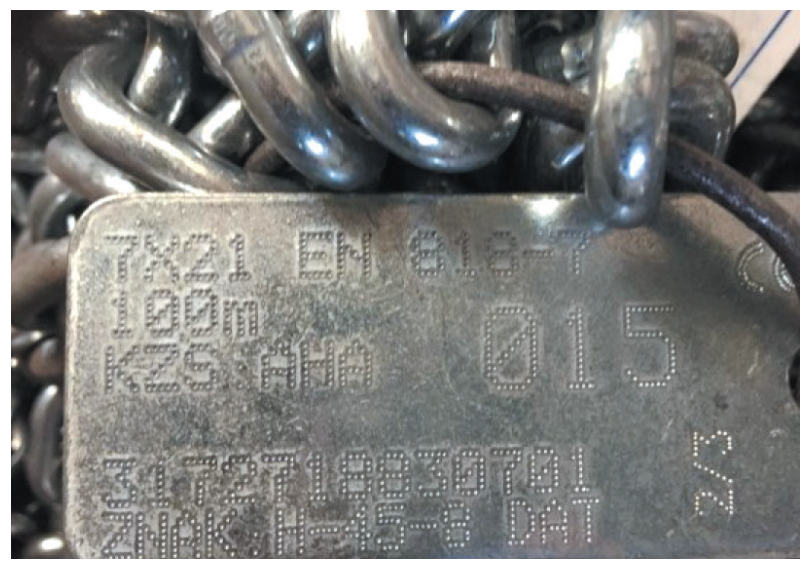

Fig. 4. Mark placed every meter at the ends of a chain

Chains produced by Retezarna a.s. meet the requirements set by the standards for the selected products.

Table 2

Chemical composition of steel for production of hoist chains - alloying elements [7]

\begin{tabular}{|l|c|c|c|}
\hline \multirow{2}{*}{ Element } & \multicolumn{2}{|c|}{ Minimum mass share in percent determined in cast analysis } \\
\cline { 2 - 4 } & type T & type DAT & type DT \\
\hline Nickel $(\mathrm{Ni})$ & 0.40 & 0.7 & $0.9^{*}$ \\
\hline Chromium (Cr) & 0.40 & 0.40 & 0.4 \\
\hline Molybdenum (Mo) & 0.15 & 0.15 & 0.15 \\
\hline
\end{tabular}

* Higher surface hardness and/or greater hardening depth require higher nickel content to avoid brittleness

Table3

Sulphur and phosphorus content in steel for production of hoist chains [7]

\begin{tabular}{|l|c|c|}
\hline \multirow{2}{*}{\multicolumn{1}{|c|}{ Element }} & \multicolumn{2}{c|}{ Minimum mass share in percent determined in } \\
\cline { 2 - 3 } & cast analysis & control analysis \\
\hline Sulfur (S) & 0.020 & 0.025 \\
\hline Phosphorus (P) & 0.020 & 0.025 \\
\hline Total sulfur + phosphorus & 0.035 & 0.045 \\
\hline
\end{tabular}


To emphasize the high quality and safety of use, the chains produced by Retezarna a.s. have the H45 mark (Manufacturer's ID) given by the DGUV Deutsche Gesetzliche Unfallversicherung certification body guaranteeing the product's compliance with the PN-EN 818-7 standard [2, 10]. Figure 5 shows the stamped quality mark on a chain link.

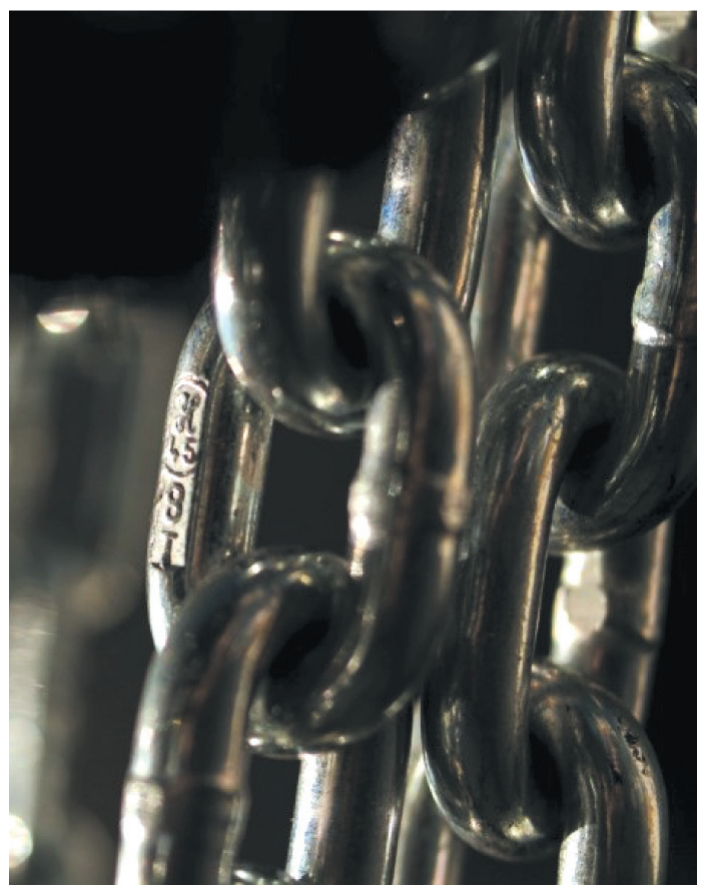

Fig. 5. H 45 quality mark embossed on chain link

Observation of the market of chain suppliers for various types of hoists and winches justifies the opinion that there are suppliers on the market who do not meet the requirements of the EU directive. Inconsistencies can be observed in the Declaration of Conformity, among others, which shows the discrepancy between the qualitative parameters of the chain and requirements contained in the Directive. This is particularly important for high-strength chains; e.g., DAT. The most common nonconformity is the use of inadequate steel; e.g., manganese steel, inadequate proportions of the $\mathrm{Ni}, \mathrm{Cr}$, Mo elements, or the absence or insufficient content of aluminum. The authors of the present article emphasize that customers pay particular attention to this issue when choosing a chain manufacturer, as it has a direct impact on the safety of the chain's users.

\section{CONCLUSIONS}

The development of mechanization systems in various branches of industry (including mining) requires the use of auxiliary devices that facilitate assembly, service, and transport work. Moving heavier and heavier weights requires the use of devices with increasingly better technical parameters. One such device belonging to the so-called "small mechanization" are winches and chain hoists [11]. In addition to the technical and constructional parameters of these devices, the chains with which goods are moved also affect their operation and safety. Therefore, from the point of view of work safety, the quality of the chain used is very important. The present article only indicates the basic elements and determinants that affect the quality of a chain. From this analysis, it is clear that, it should be noted whether the product has a certificate with the designation $x$ when choosing chains (which is a prestigious certificate ensuring that the manufacturer meets the requirements of the European standards). It is also necessary to verify the mechanical properties of the material from which the chains are made and pay attention to their quality. For each chain intended for hoists and winches, the customer should receive documents such as a declaration of conformity, manual, and inspection certificate. A material certificate is not required, but the chain producer should provide it upon a client's request. Additionally, a confirmation of the quality of the material used and the manufacturing of the chain is the manufacturer's certificate, which is supplied with the product.

\section{Acknowledgements}

The article was financed from the fund of statutory work 13/030 / BK_18 / 0039 carried out at the Institute of Production Engineering at the Faculty of Organization and Management of the Silesian University of Technology.

\section{References}

[1] https://www.ciop.pl.

[2] Midor K.: Significance of the quality of short - link chains for work environment, in: Ulewicz R., Hadzima B. (ed.), 12th International Conference Quality Production Improvement 2018 QPI'18. Book Series: MATEC Web of Conferences 17 Ave du Hoggar Parc d activites Coutaboeuf BP 112, F-91944 Cedex a, France: EDP Sciences, 2018.

[3] Piatkiewicz A., Sobolski R.: Dźwignice, t. 2, WNT, Warszawa 1977.

[4] www.snoork.pl.

[5] PPUH “Anima” Krzysztof Śleziak: Warunki techniczne wykonania i odbioru, nr ANW-17.06/WT. 
[6] Cebula D., Kalita M.: Proces projektowania wciagników tańcuchowych, "Maszyny Górnicze" 2014, 1: 22-28.

[7] PN-EN 818-7:2002+A1:2008: Bezpieczeństwo - Łańcuch o ogniwach krótkich do podnoszenia tadunków - Część 7: Dokładny tańcuch dźwignicy - Klasa T (Typy T, DAT i DT).

[8] PN-G-46732:1997: Wciagniki górnicze tańcuchowe - Łańcuchy krótkoogniwowe kalibrowane.

[9] PN-EN 10025:2002: Wyroby walcowane na goraco z niestopowych stali konstrukcyjnych - Warunki techniczne dostawy.

[10] Midor K., Biały W.: Łańcuch krótkoogniwowy - determinanty wptywajace na bezpieczeństwo pracy, "Systemy Wspomagania w Inżynierii Produkcji” 2018, 7, 1: 497-505.

[11] Kalita M.: Wciagarka tańcuchowa układaka przewodów kompleksu MIKRUS, "Maszyny Górnicze" 2013, 3: 21-25.
KATARZYNA MIDOR, Ph.D., Eng. WITOLD BIAŁY, Assoc. prof. Faculty of Organization and Management Silesian University of Technology ul. Roosevelta 26, 41-800 Zabrze, Poland $\{$ katarzyna.midor,witold.bialy\}@polsl.pl

JURAJ RUŽBARSKÝ, Ph.D., Eng., Assoc. prof. Tecgnical University of Kosice Bayerova 1, 08001 Preszew, Slovakia juraj.ruzbarsky@tuke.sk 
KATARZYNA MIDOR

WITOLD BIAEY

JURAJ RUŽBARSKÝ

\title{
Znaczenie jakości łańcuchów dla bezpieczeństwa pracy
}

\begin{abstract}
Jakość zastosowanego tańcucha w urządzeniach dźwigowych ma bardzo duże znaczenie $w$ środowisku ich pracy. Ważnym eksploatacyjnym elementem we wciagnikach $i$ wciqgarkach tańcuchowych jest tańcuch o ogniwach krótkich, który stanowi w dużej mierze o bezpieczeństwie pracownika obstugującego dźwignicę. W artykule omówiono podstawowe elementy wptywajace na jakość $i$ bezpieczeństwo tańcucha. $Z$ analizy jednoznacznie wynika, iż użytkownicy tych produktów przy wyborze dostawcy nie powinni sugerować się tylko cena, ale przede wszystkim certyfikatami i atestami produktu.
\end{abstract}

Słowa kluczowe: łańcuch, wciagnik/wciagarka, jakość, bezpieczeństwo pracy

\section{WPROWADZENIE}

Środowisko pracy wywiera duży wpływ na zdrowie i na jakość życia pracownika, gdyż składa się na nie zespół czynników materialnych i psychospołecznych, z którymi pracownik styka się podczas wykonywania pracy lub przysposobienia do niej. Do czynników materialnych środowiska pracy zalicza się m.in. teren przedsiębiorstwa lub instytucji, budynki, pomieszczenia, maszyny, narzędzia, urządzenia, a także czynniki o charakterze fizycznym i chemicznym (np. mikroklimat, oświetlenie, drgania, hałas, czynniki mechaniczne oraz substancje chemiczne i pyłowe) i czynniki biologiczne. Natomiast do czynników psychospołecznych (niematerialnych) środowiska pracy zalicza się m.in.: wymagania psychologiczne pracy, czynniki organizacyjne, partycypację pracowników, stosunki międzyludzkie, rozwój kariery zawodowej i kulturę organizacyjną $[1,2]$.

$\mathrm{W}$ artykule został omówiony jeden $\mathrm{z}$ elementów środowiska pracy w przemyśle wpływający na bezpieczeństwo pracownika, a mianowicie urządzenia dźwignicowe, których ważnym elementem eksploatacyjnym jest łańcuch.

Dźwignice to grupa urządzeń dźwigowo-transportowych, służących do przemieszczania pionowego bądź poziomego ładunków, zwierząt i ludzi na niewielkie odległości w ruchu przerywanym. W klasycz- nej literaturze [3] w podziale dźwignic wyróżniamy: dźwigniki, cięgniki, wózki, suwnice, żurawie. Ze względu na zagadnienia poruszane $\mathrm{w}$ artykule autorów interesują cięgniki, które dzielą się między innymi na takie urządzenia, jak wciągarki i wciągniki. Te dwa urządzenia - dźwignice przystosowane są do pionowego podnoszenia ładunku za pomocą liny lub łańcucha $\mathrm{z}$ wykorzystaniem elementu chwytnego zazwyczaj haka, a różnica pomiędzy nimi występuje w zamocowaniu konstrukcji nośnej. W zależności od sposobu skonstruowania wspomniane urządzenia mogą być wykorzystywane w różnych przestrzeniach, takich jak: przemysł, budownictwo, motoryzacja czy przemysł leśny [4].

W pracy wielu dźwignic, zwłaszcza o napędzie ręcznym, stosowane są łańcuchy jako elementy udźwigowe. Łańcuchów używa się również jako część składową zawiesi łańcuchowych do obwiązywania i zawieszenia ciężarów na hak dźwignic ręcznych i mechanicznych.

Łańcuchy stosowane w dźwignicach jako elementy udźwigowe można podzielić na dwa rodzaje: łańcuchy ogniwowe i łańcuchy płytkowe przegubowe zwane łańcuchami Galla - rysunek 1. Te dwa rodzaje łańcuchów nazywamy łańcuchami technicznymi, które są niezastąpione $\mathrm{w}$ wielu branżach przemysłowych i gospodarczych i są przeznaczone do przenoszenia większych obciążeń. 
a)

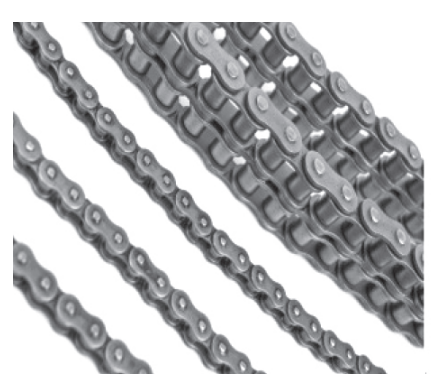

b)

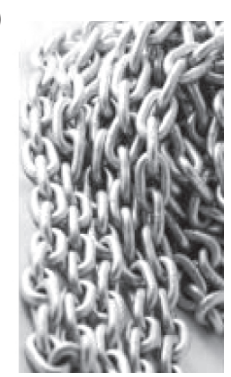

Rys. 1. Łańcuch rolkowy napędowy Galla (a); tańcuch zawiesiowy ogniwowy (b)

Podstawowym pojęciem charakteryzującym łańcuch jest tzw. wielkość łańcucha. Wielkość ta zdefiniowana jest jako iloczyn średnicy pręta $d$, z którego zrobione jest ogniwo oraz największego wymiaru wewnętrznego $p$ nazywanego podziałką ogniwa lub łańcucha. Ponadto ogniwo charakteryzuja jeszcze wielkości: $a$ - długość wewnętrzna mierzona w świetle ogniwa, $b$ - szerokość zewnętrzna ogniwa oraz „L11p” - wewnętrzna długość łańcucha z jedenastoma ogniwami [5]. Wymienione wymiary ogniwa zaprezentowane są na rysunku 2. W zależności od długości ogniwa łańcuchy dzielimy na krótko- bądź długoogniwowe. Łańcuchem krótkoogniwowym nazywamy łańcuch, którego długość ogniwa nie przekracza pięciokrotnej średnicy pręta $d$, z którego ogniwo zostało wykonane, a szerokość $b$ nie jest większa niż 3,5-krotna średnica pręta. Jeśli długość ogniwa przekracza pięciokrotną średnicę pręta $d$, to łańcuchy takie zaliczone są do długoogniwowych.

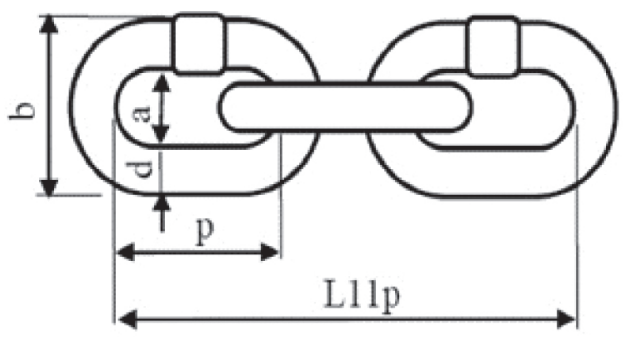

Rys. 2. Wymiary ogniwa/tańcucha [5]

Łańcuchy o ogniwach krótkich mają zastosowanie w szeregu urządzeń mechanicznych, głównie jako łańcuchy napędowe, współpracujące z kołami gniazdowymi oraz zawiesia pomocnicze $\mathrm{w}$ ciągnikach. Łańcuchy o ogniwach długich są łańcuchami ogólnego przeznaczenia i szczególne mają zastosowanie w przemyśle górniczym.

W artykule uwaga zostanie zwrócona na łańcuchy o ogniwach krótkich, które są stosowane przede wszystkim we wciągnikach i wciągarkach.
Wciagniki ze względu na rodzaj napędu możemy podzielić na: ręczne, elektryczne oraz pneumatyczne. Natomiast podział ze względu na rodzaj zastosowanego cięgna dzieli te urządzenia na łańcuchowe lub linowe. Przykłady takich wciągników zaprezentowano na rysunku 3. a)

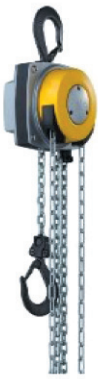

b)

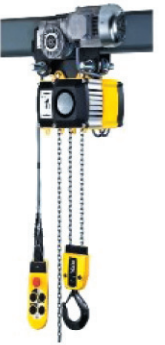

c)



Rys. 3. Przyktady rodzajów wciagników: a) ręczny wciagnik łańcuchowy modelYale lift 360; b) wciagnik tańcuchowy model CPV z napędem elektrycznym; c) wciagnik tańcuchowy $z$ napędem pneumatycznym model CPA 1-13

Łańcuchy o ogniwach krótkich do podnoszenia ładunków, można stosować w wielu branżach przemysłowych i gospodarczych, w tym między innymi w podziemnych wyrobiskach zakładów górniczych, w przestrzeniach zagrożonych wybuchem pyłu węglowego oraz metanu.

Na rynku polskim jest kilku producentów omawianych łańcuchów, m.in.: Pewag Polska Sp. z o.o., Grupa RUD, THIELE, Retezarna a.s.

W artykule autorzy omawiają łańcuchy produkowane przez firmę Retezarna a.s.

\section{WYMAGANIA PRAWNE STAWIANE ŁAŃCUCHOM O KRÓTKICH OGNIWACH}

W przemyśle górniczym do transportu bliskiego stosowane są między innymi wciągniki z cięgnem łańcuchowym, umożliwiające montaż podzespołów maszyn i urządzeń oraz przemieszczanie materiałów. Ze względu na trudne warunki eksploatacji w ograniczonych przestrzeniach wyrobisk i komór montażowych, urządzenia dźwignicowe, przeznaczone dla przemysłu górniczego oprócz odpowiedniego udźwigu muszą charakteryzować się dużą prędkością podnoszenia, niewielką masą własną, niewielkimi gabarytami oraz bezpieczeństwem pracy [6].

Ważnym eksploatacyjnym elementem w tych urządzeniach jest łańcuch, który stanowi w dużej mierze 
o bezpieczeństwie pracownika obsługującego dźwignicę. Każdy łańcuch, który jest wykorzystywany w przemyśle na terenie Unii Europejskiej, musi być zgodny z Dyrektywą 2006/42/WE Parlamentu Europejskiego i Rady z dnia 17 maja 2006 r. w sprawie maszyn, odnoszącej się między innymi do bezpieczeństwa i ochrony zdrowia pracowników pracujących z urządzeniami i maszynami, których ruchomym elementem jest łańcuch. A zatem łańcuchy przeznaczone do podnoszenia ładunków, które są standardowo używane w UE, w tym także w Polsce, muszą być produkowane zgodnie $\mathrm{z}$ powyższą dyrektywą oraz $\mathrm{z}$ wymaganiami takich norm, jak:

- EN 818-2 + A1. Norma dla łańcuchów o średniej tolerancji dla zacisków łańcuchowych - klasa 8 (800 MPa) charakteryzujących się stosunkiem współczynników bezpieczeństwa 4:2,5:1 (siła zrywająca/ siła testowa/ nośność). Łańcuch musi być testowany. Ograniczenia temperatury $-40^{\circ} \mathrm{C}$ do $+400^{\circ} \mathrm{C}$;

- EN 818-7 + A1. Norma, w której opisano wymagania łańcucha do wciągnika/ wciągarki łańcuchowej, zależnie od konstrukcji, ciężaru ładunku i środowiska, w którym jest używany.

Łańcuch $T$ używany we wciągnikach/ wciągarkach $\mathrm{z}$ napędem ręcznym lub $\mathrm{w}$ podnośnikach $\mathrm{z}$ napędem silnikowym o małych prędkościach, które nie pracują w warunkach abrazyjnych. Współczynnik bezpieczeństwa łańcucha powinien mieć stosunek $4: 2,5: \mathrm{x}$ (siła zrywająca/ siła testowa/ nośność zgodnie $\mathrm{z}$ napędami ISO 4301-1). Łańcuch powinien być skalibrowany, przetestowany. Ograniczenia temperatury od $-40^{\circ} \mathrm{C}$ do $+200^{\circ} \mathrm{C}$.

DAT łańcuch używany we wciągnikach/ wciągarkach $\mathrm{z}$ napędem silnikowym, które osiągają duże prędkości, w połączeniu $\mathrm{z}$ dużym natężeniem pracy w miejscach, gdzie jest wymagana odporność na ścieranie, związana ze zwiększeniem żywotności łańcucha. Współczynnik bezpieczeństwa powinien mieć stosunek $4: 2,5: x$ (siła zrywająca/ siła testowa/ nośność zgodnie z napędami ISO 4301-1). Łańcuch powinien być skalibrowany, przetestowany. Ograniczenia temperatury od $-20^{\circ} \mathrm{C}$ do $+200^{\circ} \mathrm{C}$.

DT łańcuch używany we wciągnikach/ wciągarkach $\mathrm{z}$ napędem silnikowym $\mathrm{w}$ abrazyjnych warunkach pracy. Współczynnik bezpieczeństwa powinien charakteryzować się stosunkiem $4: 2,5: x$ (siła zrywająca/ siła testowa/ nośność zgodnie $\mathrm{z}$ napędami ISO 4301-1). Łańcuch powinien być skalibrowany, przetestowany. Zakres temperatur: od $-10^{\circ} \mathrm{C}$ do $+200^{\circ} \mathrm{C}$.
Ponadto na terenie Polski obowiązują także normy techniczne oraz akty prawne i spełnienie ich wymagań gwarantuje bezpieczeństwo dla użytkownika łańcucha. Są to między innym takie dokumenty, jak:

- PN-G-46732:1997: Wciagniki górnicze tańcuchowe - Łańcuchy krótkoogniwowe kalibrowane;

- Wymagania bezpieczeństwa uwzględniajace postanowienia Ustawy $z$ dnia 9 czerwca 2011 r. - Prawo geologiczne i górnicze (Dz.U. z 2017 r., poz. 2126, ze zmianami);

- Rozporzadzenie Ministra Gospodarki z dnia 28 czerwca 2002 r. $w$ sprawie bezpieczeństwa $i$ higieny pracy, prowadzenia ruchu oraz specjalistycznego zabezpieczenia przeciwpożarowego $w$ podziemnych zakładach górniczych (Dz.U. z 2002, nr 139, poz. 1169);

- Ustawa z dnia 12 grudnia 2003 r. o ogólnym bezpieczeństwie produktów (Dz.U. z dnia 31 grudnia 2003 r.);

- PN-EN 10025:2002: Wyroby walcowane na goraco $z$ niestopowych stali konstrukcyjnych;

- PN-EN ISO 643:2013-06: Stal - Mikrograficzne określanie wielkości ziarna;

- PN-EN ISO 6507-1:2018-05: Metale - Pomiar twardości sposobem Vickersa - Część 1: Metoda badań.

\section{WYMAGANIA TECHNICZNE STAWIANE ŁAŃCUCHOM O KRÓTKICH OGNIWACH}

Firma Retezarna a.s. w swojej ofercie ma standardowe rozmiary łańcuchów, które zostały przedstawione w tabeli 1. Ponadto mogą być produkowane łańcuchy w rozmiarach na specjalne zamówienie klienta [5].

Łańcuchy ogniwowe wykonane są ze stali o wytrzymałości na rozrywanie odpowiedniej dla danej klasy łańcucha. Składają się one z ogniw zgrzewanych w ogniu lub elektrycznie.

Łańcuchy spawane do wciągników i wciagarek łańcuchowych klasy T (w wykonaniu T, DAT, DT) muszą charakteryzować się wysoką jakością, doskonałymi walorami użytkowymi i długą żywotnością. Aby to spełnić, muszą być wykonywane z największą starannością, tak aby zapewnić bezpieczeństwo podczas ich użytkowania.

Parametrami determinującymi jakość i bezpieczeństwo użytkowania łańcuchów są m.in. właściwości mechaniczne i obciążenia. Do produkcji łańcuchów przeznaczonych do wciągarek/ wciągników wykorzystywana jest stal o właściwościach mechanicznych zgodnych z normą PN-EN 10025 [7-9], aby finalny produkt spełniał wszystkie wymagania 
określane przez rygorystyczne standardy europejskie zgodnie z normami PN-EN 818-7 oraz PN-G-46732. Norma europejska EN8-18-7 +A1:2008 obowiązująca również na terenie Polski stawia jasno określone wymagania co do rodzaju stali, z jakiej ma być wykonany łańcuch, w jakim procesie powinna być wypro- dukowana stal oraz jaki powinna mieć skład chemiczny. W tabelach 2 i 3 zaprezentowano wymagania stawiane zawartości pierwiastków w stali. W celu zabezpieczenia łańcucha przed starzeniem w czasie jego użytkowania stal powinna zawierać co najmniej $0,025 \%$ aluminium $(\mathrm{Al})$.

Tabela 1

Standardowe rozmiary łańcuchów firmy Retezarna a.s. [5]

\begin{tabular}{|c|c|c|c|c|c|c|c|c|c|}
\hline $\begin{array}{c}\text { Wielkość } \\
\text { lańcucha } \\
d \times p\end{array}$ & & $l$ & $p$ & $\begin{array}{c}a \text { nie } \\
\text { mniej } \\
\text { niz }\end{array}$ & $\begin{array}{c}b \text { nie } \\
\text { więcej niż }\end{array}$ & \multirow{2}{*}{$\begin{array}{c}\begin{array}{c}\text { Masa } \\
1 \mathrm{~m} \\
\text { lańcucha }\end{array} \\
{[\mathrm{kg}]} \\
\end{array}$} & $\begin{array}{c}\text { Dlugość } \\
\text { nominalna } \\
L=11 \times p\end{array}$ & Tolerancja & \multirow[t]{2}{*}{$\begin{array}{c}\text { Maks. } \\
\text { średnica } \\
\text { spoiny }\end{array}$} \\
\hline \multicolumn{6}{|c|}{$[\mathrm{mm}]$} & & \multicolumn{2}{|c|}{$[\mathrm{mm}]$} & \\
\hline $4 \times 12$ & 4 & $\pm 0,2$ & 12 & 4,8 & 13,6 & 0,35 & 132 & 0,6 & 4,3 \\
\hline $5 \times 15$ & 5 & $\pm 0,2$ & 15 & 6,0 & 17,0 & 0,54 & 165 & 0,8 & 5,4 \\
\hline $6 \times 18$ & 6 & $\pm 0,2$ & 18 & 7,2 & 20,4 & 0,8 & 198 & 1,0 & 6,5 \\
\hline $7 \times 21$ & 7 & $\pm 0,3$ & 21 & 8,4 & 23,8 & 1,1 & 231 & 1,1 & 7,6 \\
\hline $8 \times 24$ & 8 & $\pm 0,4$ & 24 & 9,6 & 27,2 & 1,4 & 264 & 1,3 & 8,6 \\
\hline $9 \times 27$ & 9 & $\pm 0,4$ & 27 & 10,8 & 30,6 & 1,8 & 297 & 1,4 & 9,7 \\
\hline $10 \times 30$ & 10 & $\pm 0,4$ & 30 & 12,0 & 34,0 & 2,2 & 330 & 1,6 & 10,8 \\
\hline $11 \times 31$ & 11 & $\pm 0,4$ & 31 & 13,2 & 37,4 & 2,7 & 363 & 1,7 & 11,9 \\
\hline $12 \times 36$ & 12 & $\pm 0,5$ & 36 & 14,4 & 47,6 & 3,1 & 396 & 1,9 & 13,0 \\
\hline $13 \times 39$ & 13 & $\pm 0,5$ & 39 & 15,6 & 44,2 & 3,7 & 429 & 2,1 & 14,0 \\
\hline $14 \times 42$ & 14 & $\pm 0,6$ & 42 & 16,8 & 47,6 & 4,3 & 462 & 2,2 & 15,1 \\
\hline $16 \times 45$ & 16 & $\pm 0,6$ & 45 & 19,2 & 54,4 & 5,6 & 528 & 2,5 & 17,3 \\
\hline $18 \times 54$ & 18 & $\pm 0,9$ & 54 & 21,6 & 61,2 & 7,0 & 594 & 2,9 & 19,4 \\
\hline $20 \times 60$ & 20 & $\pm 1,0$ & 60 & 24,0 & 68,0 & 8,7 & 660 & 3,2 & 21,6 \\
\hline $22 \times 66$ & 22 & $\pm 1,1$ & 66 & 26,4 & 74,8 & 10,5 & 726 & 3,5 & 23,8 \\
\hline
\end{tabular}

Tabela 2

Skład chemiczny stali do produkcji łańcuchów do dźwignic - pierwiastki stopowe [7]

\begin{tabular}{|l|c|c|c|}
\hline \multirow{2}{*}{ Pierwiastek } & \multicolumn{2}{|c|}{ Minimalny masowy udzial określony w analizie wytopu: } \\
\cline { 2 - 4 } & typu T [\%] & typu DAT [\%] & typu DT [\%] \\
\hline Nikiel (Ni) & 0,40 & 0,7 & $0,9^{*}$ \\
\hline Chrom (Cr) & 0,40 & 0,40 & 0,4 \\
\hline Molibden (Mo) & 0,15 & 0,15 & 0,15 \\
\hline
\end{tabular}

* Większa twardość powierzchni i/lub większa głębokość hartowania wymagają większej zawartości niklu, aby uniknąć kruchości

Tabela 3

Zawartość siarki i fosforu w stali do produkcji łańcuchów do dźwignic [7]

\begin{tabular}{|l|c|c|}
\hline \multirow{2}{*}{ Pierwiastek } & \multicolumn{2}{|c|}{ Największy masowy udzial określony w: } \\
\cline { 2 - 3 } & analizie wytopu [\%] & analizie kontrolnej [\%] \\
\hline Siarka $(\mathrm{Si})$ & 0,020 & 0,025 \\
\hline Fosfor $(\mathrm{P})$ & 0,020 & 0,025 \\
\hline Suma siarki i fosforu & 0,035 & 0,045 \\
\hline
\end{tabular}


Normy wymagają także od producenta poddania łańcucha procesowi kalibracji. Istotnym elementem wpływającym na bezpieczeństwo użytkowania łańcucha jest jakość jego wykonania ze szczególnym uwzględnieniem odchyłek od wymiarów, które zostaky zawarte w tabeli 1 . Ponadto norma PN-EN 818-7 wymaga od producenta stosowania złożonego programu badań jakości wyrobu w celu zapewnienia bezpieczeństwa podczas eksploatacji łańcucha. Szczególny nacisk położony jest na zastosowanie odpowiednich gatunków stali jako materiałów, z których wykonane są elementy łańcucha krótkiego w klasie T. Każda dostawa do klienta musi być oznaczona znakiem producenta, grubością łańcucha, numerem serii produkcyjnej, długością łańcucha oraz liczbą sztuk w serii. $\mathrm{Na}$ końcach łańcucha co metr umieszcza się cechę zawierającą: znak producenta, rok produkcji, liczbę oznaczającą miesiąc produkcji i klasę łańcucha (T, DAT lub DT - dla normy 818-7); 5,6 lub 8 dla normy PN-G-46732 - rysunek 4.



Rys. 4. Cecha umieszczana na końcach tańcucha po każdym metrze

Produkowane łańcuchy w Retezarni a.s. spełniają wymagania stawiane $\mathrm{w}$ normach wybranym produktom. Łańcuchy produkcji Retezarna a.s, dla podkreślenia wysokiej jakości i bezpieczeństwa stosowania posiadają znak H45 (identyfikator producenta) nadany przez jednostkę certyfikującą DGUV Deutsche Gesetzliche Unfallversicherung gwarantujący zgodność produktu z normą PN-EN 818-7 [2, 10]. Na rysunku 5 pokazano wybity znak jakości na ogniwie łańcucha.

Obserwacja rynku dostawców łańcuchów do różnego rodzaju wciągników i wciągarek pozwala na wyrażenie opinii, iż nie wszyscy dostawcy spełniają wymagania dyrektywy unijnej. Między innymi z dokumentu „deklaracja zgodności” wynika rozbieżność pomiędzy jakościowymi parametrami łańcucha a wymaganiami zawartymi w dyrektywie. Ma to szczególne znaczenie dla łańcuchów o wysokiej wytrzymałości, np. DAT. Najczęstszą nieprawidłowością jest zastosowanie nieodpowiedniej stali, np. stali manganowej, bądź też nieodpowiednich proporcji pierwiastków NI, Cr, Mo oraz braku bądź zbyt małej zawartości pierwiastka Al. Autorzy artykułu zachęcają, aby klienci zwracali szczególną uwagę na to zagadnienie przy wyborze producenta łańcuchów, ponieważ ma to bezpośredni wpływ na bezpieczeństwo użytkownika łańcucha.

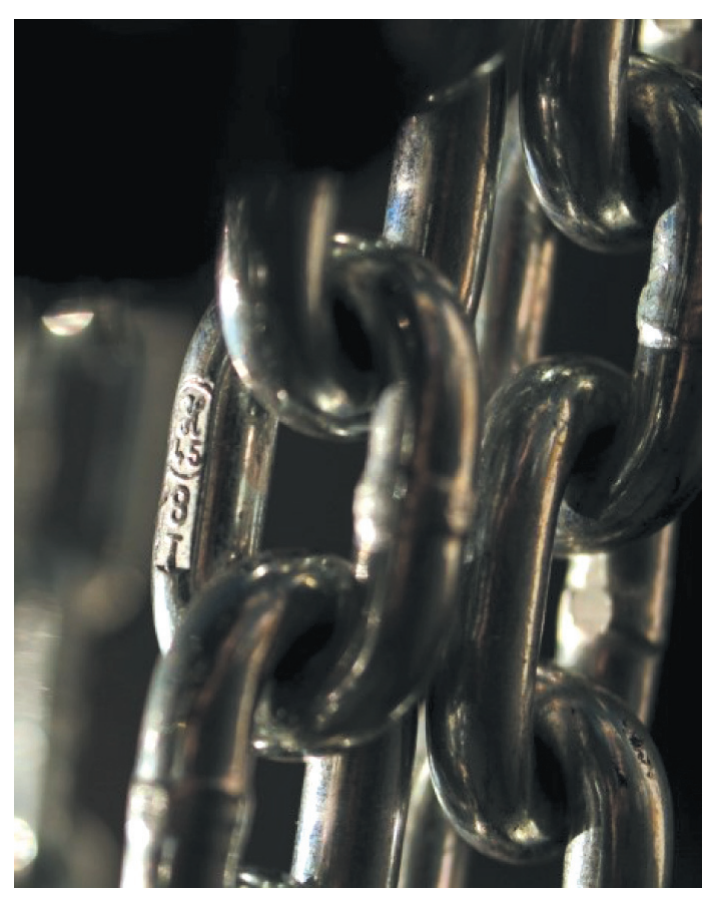

Rys. 5. Cecha umieszczana na końcach tańcucha po każdym metrze

\section{PODSUMOWANIE}

Rozwój systemów mechanizacyjnych w różnych gałęziach przemysłu, w tym także w górnictwie, wymaga stosowania urządzeń pomocniczych, wspomagających prowadzenie prac montażowych, serwisowych czy transportowych. Przemieszczanie coraz większych mas wymaga stosowania urządzeń o coraz lepszych parametrach technicznych. Jednymi z takich urządzeń należących do tak zwanej „małej mechanizacji” są wciągarki i wciągniki łańcuchowe [11]. Poza parametrami technicznymi i konstrukcyjnymi tych urządzeń na pracę i bezpieczeństwo wpływa łańcuch, za pomocą którego są przemieszczane towary. Dlatego też z punktu widzenia bezpieczeństwa pracy jakość zastosowanego łańcucha ma bardzo duże znaczenie. 
W artykule zasygnalizowano tylko podstawowe elementy i determinanty, które wpływają na jakość łańcucha. $\mathrm{Z}$ tej analizy jednoznacznie wynika, że przy wyborze łańcuchów należy zwrócić uwagę na to, czy produkt posiada certyfikat $\mathrm{z}$ oznaczeniem $\varkappa$, który jest prestiżowym certyfikatem zapewniającym o spełnianiu przez producenta wymagań norm europejskich. Należy także weryfikować właściwości mechaniczne materiału, z którego zrobione są łańcuchy, oraz powinno się zwracać uwagę na jakość ich wykonania. Do każdego łańcucha do wciągników i wciągarek klient powinien otrzymać dokumenty, takie jak: deklaracja zgodności, instrukcja użytkowania, certyfikat kontroli. Certyfikat materiałowy nie jest wymagany, ale na życzenie klienta producent łańcucha powinien go udostępnić. Ponadto potwierdzeniem jakości zastosowanego materiału oraz wykonania łańcucha jest atest producenta, który jest dostarczany wraz z wyrobem.

\section{Podziękowania}

Artykuł został sfinansowany ze środków pracy statutowej 13/030/BK_18/0039 realizowanej w Instytucie Inżynierii Produkcji na Wydziale Organizacji i Zarządzania Politechniki Śląskiej.

\section{Literatura}

[1] https://www.ciop.pl.

[2] Midor K.: Significance of the quality of short - link chains for work environment, w: Ulewicz R., Hadzima B. (red.), 12th International Conference Quality Production Improvement 2018 QPI'18. Book Series: MATEC Web of Conferences 17 Ave du Hoggar Parc d activites Coutaboeuf BP 112, F-91944 Cedex a, France: EDP Sciences, 2018.
[3] Piątkiewicz A., Sobolski R.: Dźwignice, t. 2, WNT, Warszawa 1977.

[4] www.snoork.pl.

[5] PPUH „Anima” Krzysztof Śleziak: Warunki techniczne wykonania i odbioru, nr ANW-17.06/WT.

[6] Cebula D., Kalita M.: Proces projektowania wciagników łańcuchowych, „Maszyny Górnicze” 2014, 1: 22-28.

[7] PN-EN 818-7:2002+A1:2008: Bezpieczeństwo - Łańcuch o ogniwach krótkich do podnoszenia ładunków - Część 7: Dokładny łańcuch dźwignicy - Klasa T (Typy T, DAT i DT).

[8] PN-G-46732:1997: Wciagniki górnicze łańcuchowe - Łańcuchy krótkoogniwowe kalibrowane.

[9] PN-EN 10025:2002: Wyroby walcowane na goraco z niestopowych stali konstrukcyjnych - Warunki techniczne dostawy.

[10] Midor K., Biały W.: Łańcuch krótkoogniwowy - determinanty wpływające na bezpieczeństwo pracy, „Systemy Wspomagania w Inżynierii Produkcji” 2018, 7, 1: 497-505.

[11] Kalita M.: Wciagarka łańcuchowa układaka przewodów kompleksu MIKRUS, „Maszyny Górnicze” 2013, 3: 21-25.

dr inż. KATARZYNA MIDOR dr hab. inż. WITOLD BIAEY, prof. PŚ

Wydziat Organizacji i Zarzadzania Politechnika Śląka

ul. Roosevelta 26, 41-800 Zabrze

\{katarzyna.midor,witold.bialy\}@polsl.pl

dr inż. JURAJ RUŽBARSKÝ

Technical University of Kośice

Bayerova 1, 08001 Preszew,

Stowacja

juraj.ruzbarsky@tuke.sk 